\title{
Pengaruh Kualitas Jasa Pelayanan Terhadap Kepuasan Konsumen Pada Toko Cahaya Di Kecamatan Laung Tuhup Kabupaten Murung Raya
}

\author{
Y. Sartika, Tonich, R. Alexandro \\ Program Studi Pendidikan Ekonomi \\ Fakultas Keguruan dan Ilmu Pendidikan \\ Universitas Palangka Raya \\ Kampus UPR Tunjung Nyaho Jalan Hendrik, Indonesia \\ (Diterima 22-11-2019; Disetujui 2-12-2019)
}

\begin{abstract}
ABSTRAK
Kualitas pelayanan ini dapat diartikan sebagai tingkat kepuasan tamu atau konsumen. Sedangkan tingkat kepuasan tamu ini sendiri dapat diperoleh dari perbandingan atas jenis pelayanan yang nyata diterima oleh konsumen dengan jenis pelayanan yang diharapkan oleh konsumen. Jenis kualitas pelayanan yang baik adalah jenis pelayanan yang memuaskan dan sesuai dengan pelayanan yang diharapkan oleh konsumen. Namun jika pelayanan ini dapat melampaui harapan konsumen, maka jenis kualitas pelayanan ini dapat dikategorikan sebagai pelayanan yang sangat berkualitas atau sangat memuaskan. Sedangkan jenis kualitas pelayanan yang buruk adalah jenis pelayanan yang berada jauh di bawah standar atau tidak sesuai dengan ekspekstasi pelayanan yang diharapkan oleh konsumen. Hasil penelitian: Diketahui Nilai F Hitung adalah sebesar 321.444. karena nilai f hitung $321.444>$ f table 2.60, maka kualitas Jasa secara simultan berpengaruh terhadap Kepuasan Konsumen.
\end{abstract}

Kata Kunci: Kualitas Jasa Pelayanan, Kepuasan Konsumen

\section{PENDAHULUAN}

Dalam era perdagangan bebas, setiap perusahaan menghadapi persaingan yang ketat. Meningkatnya intensitas persaingan menuntut perusahaan selalu memperhatikan kebutuhan dan keinginan konsumen serta berusaha memenuhi harapan konsumen dengan cara memberikan pelayanan yang lebih memuaskan daripada yang dilakukan pesaing. Kualitas memiliki hubungan yang erat dengan kepuasan konsumen . kualitas memberikan suatu dorongan kepada konsumen untuk menjalin ikatan hubungan yang kuat dengan perusahaan. Dalam jangka panjang, ikatan seperti ini memungkinkan perusahaan untuk memahami dengan seksama harapan konsumen serta kebutuhan mereka.

Kini semakin disadari bahwa kualitas jasa dan kepuasan konsumen merupakan aspek penting dalam rangka mempertahankan bisnis dan memenangkan persaingan. Sukses tidaknya suatu perusahaan ditentukan oleh kemampuan perusahaan itu sendiri dalam memberikan pelayaan atau jasa untuk memuaskan konsumennya. Kepuasan konsumen bisa menjadi senjata andalan untuk tampil sebagai pemenang dalam persaingan tetapi bisa juga sebaliknya, dimana hal itu bisa menjadi bumerang yang dapat menghancurkan posisi perusahaan dalam dunia bisnis yang semakin banyak.

Banyak aspek yang menjadi pertimbangan seorang konsumen untuk memilih salah satu toko cahaya yang menjual produk yang diinginkannya. Ketika pergi ke sebuah pusat perbelanjaan, seorang konsumen cenderung menjadi seorang yang pemilih, atau selalu memiliki pertimbanganpertimbangan tersendiri sebelum memilih dan memutuskan untuk membeli sebuah produk. Seorang konsumen sengaja berkunjung ke toko cahaya tentunya memiliki tujuan untuk mendapatkan barang yang ia cari. Namun, aspek-aspek apakah yang seharusnya menjadi pertimbangan utama dalam 
memilih salah satu dari toko-toko tersebut, Tentunya selain aspek harga dan ketersediaan barang, hal lain yang dicari konsumen adalah kualitas pelayanan toko.

Terdapat beberapa pertimbangan yang menjadi tolak ukur tingkat kepuasan konsumen terhadap suatu barang. Ketika seorang konsumen telah menemukan produk yang diinginkannya, masih terdapat beberapa hal lain yang menjadi pertimbangan. Seperti misalnya pertimbangan harga barang, kualitas barang, masa garansi, atau tentang tingkat kualitas pelayanan yang baik.

Kualitas jasa atau kualitas pelayanan jasa atau customer service ini dapat dibedakan ke dalam dua kriteria yaitu jenis kualitas pelayanan yang baik dan kualitas pelayanan yang buruk. Kualitas pelayanan ini bukanlah suatu hal yang permanen atau kaku, melainkan fleksibel dan dapat dirubah. Perubahan ini tentunya berupa peningkatan kualitas pelayanan agar semakin lebih baik lagi. Dalam proses perubahan kualitas pelayanan tersebut diperlukan beberapa hal untuk menunjang prosesnya. Misalnya survei atau observasi kepada pelanggan, termasuk didalamnya berupa masukan, pendapat maupun umpan tentang pelayanan yang telah diberikan.

Kualitas pelayanan ini dapat diartikan sebagai tingkat kepuasan tamu atau konsumen. Sedangkan tingkat kepuasan tamu ini sendiri dapat diperoleh dari perbandingan atas jenis pelayanan yang nyata diterima oleh konsumen dengan jenis pelayanan yang diharapkan oleh konsumen. Jenis kualitas pelayanan yang baik adalah jenis pelayanan yang memuaskan dan sesuai dengan pelayanan yang diharapkan oleh konsumen. Namun jika pelayanan ini dapat melampaui harapan konsumen, maka jenis kualitas pelayanan ini dapat dikategorikan sebagai pelayanan yang sangat berkualitas atau sangat memuaskan.

Kualitas pelayanan ini menjadi penting karena akan berdampak langsung pada citra perusahaan. Kualitas pelayanan yang baik akan menjadi sebuah keuntungan bagi perusahaan. Bagaimana tidak, jika suatu perusahaan sudah mendapat nilai positif di mata konsumen, maka konsumen tersebut akan memberikan feedback (umpan balik) yang baik, serta bukan tidak mungkin akan menjadi pelanggan tetap. Maka dari itu, sangat penting untuk mempertimbangkan aspek kepuasan pelanggan terkait kualitas pelayanan yang diberikan. Jenis-jenis pelayanan yang dapat diberikan misalnya berupa kemudahan, kecepatan, kemampuan, dan keramahtamahan yang ditunjukkan melalui sikap dan tindakan langsung kepada konsumen.

Kualitas pelayanan didasarkan pada indikator-indikator: Pertama, Tangibles, artinya kualitas pelayanan publik yang berupa sarana fisik perkantoran. Kedua, Reliability, yaitu kemampuan dan keandalan untuk menyediakan pelayanan yang terpercaya. Ketiga, Responsiveness, yaitu kesanggupan untuk membantu dan menyediakan pelayanan secara cepat \& tepat, serta tanggap terhadap keinginan konsumen. Keempat, Assurance, yaitu kemampuan dan keramahan serta sopan santun pegawai dalam meyakinkan dan menumbuhkan kepercayaan konsumen dan terakhir Emphaty, yaitu sikap tegas tetapi penuh perhatian dari pegawai terhadap konsumen.

Toko cahaya merupakan toko bangunan yang ada di Muara Laung Kabupaten Murung Raya. Salah satu toko yang menyediakan penjualan berbagai macam produk bangunan dan material, elektronik, dan isi ulang air galon. Toko cahaya juga memberikan pelayanan prima untuk mengoptimalkan kepuasan konsumen. Selain mempertahankan konsumen serta menarik konsumen baru maka toko cahaya selalu melakukan evaluasi terhadap kualitas pelayanan seperti memperhatikan tampilan dan ruang tamu konsumen, memberikan senyum sapa kepada pelanggan serta tanggap dalam memenuhi kebutuhan konsumen dalam berbelanja. Berdasarkan observasi sementara peneliti melihat ada keterkaitan antara kualitas jasa terhadap kepuasan konsumen. Hal ini dimana kualitas jasa mampu berkontribusi positif terhadap kepuasan konsumen. Toko cahaya juga dengan konsisten mempertahankan kualitas pelayanan sehingga konsumen merasa puas dalam berbelanja di toko gemilang tersebut. 


\section{METODE PENELITIAN}

Desain penelitian ini menggunakan observasional analitik dengan rancangan Cross Sectional, yaitu untuk mengetahui pengaruh antara variabel kualitas jasa pelayanan terhadap kepuasan konsumen. Dengan penelitian ini, maka dapat dibangun suatu teori yang dapat berfungsi untuk menjelaskan, meramal, memprediksi dan mengontrol suatu gejala. Penelitian ini bersifat kuantitatif. Penelitian ini dilaksanakan di Toko cahaya Jalan Alisatri RT 13, RW 10 Muara Laung 1 Kecamatan Muara Laung Kabupaten Murung Raya. Dalam penelitian ini populasinya adalah keseluruhan konsumen yang melakukan transaksi atau pembelian di toko Cahaya. Sampel yang digunakan dalam penelitian ini adalah konsumen yang melakukan pembelian selama penelitian berlangsung. Teknik pengambilan sampel dalam penelitian ini menggunakan metode purposive sampling.

Untuk memperoleh data dan informasi yang diperlukan dalam penelitian ini adalah metode pengumpulan data. Adapun metode yang digunakan peneliti untuk penguumpulan data adalah dokumentasi dan kuisioner. Skala pengukuran dalam penelitian mi menggunakan Skala Likert. Skala Likert adalah skala yang digunakan untuk mengukur sikap, pendapatan dan persepsi seorang atau sekelompok orang tertentu tentang suatu objek atau fenomena tertentu.

Analisis statistik deskriptif digunakan untuk memberikan gambaran atau deskripsi empiris atas data yang dikumpulkan dalam penelitian. Dalam penelitian ini analisis deskritif menggambarkan persepsi responden atas masing-masing indikator variabel Bukti Langsung, Kehandalan, Daya Tanggap, Jaminan, Empati, dan Kepuasan konsumen. Metode uji validitas ini dengan cara mengkolerasikan masing-masing skor item dengan skor total item. Penguji yang dilakukan dengan menggunakan SPSS Statistics. Butir pertanyaan sudah dinyatakan valid dalam uji validitas akan ditentukan reliabilitasnya. Lalu akan dilakukan uji asumsi klasik dan uji regresi linier bergada dan uji asumsi klasik. Dalam penelitian ini digunakan taraf signifikansi sebesar 5\% dan derajat kebebasan (d.f) $=\mathrm{n}-\mathrm{k}$, dapat diketahui dari hasil perhitungan computer program SPSS. Kesimpulan yang diambil adalah: Jika $t_{\text {hitung }}>t_{\text {tabel }}$ tabel pada alpha $=5 \%$, maka Ho ditolak dan Ha diterima, artinya variabel independen secara parsial mempunyai pengaruh signifikan terhadap variabel dependen. Jika $t_{\text {hitung }}<\mathrm{t}_{\text {tabel }}$ tabel pada alpha $=5 \%$, maka Ho diterima dan Ha ditolak, artinya variabel independen secara parsial tidak mempunyai pengaruh signifikan terhadap variabel dependen.

\section{HASIL DAN PEMBAHASAN}

\section{Uji Validitas dan Reliabilitas}

Ada 2 cara menganalisis indikator yang valid.

1. Indikator dikatakan valid jika indikator tersebut memiliki koefisien korelasi $r>r$ table. $R$ table dengan $\mathrm{N}=30$ adalah 0.361 . Koefisien korelasi yang dimaksud adalah koefisien $\mathrm{r}$ antara indikator dengan total.

2. Indikator dikatakan valid jika indikator memiliki nilai signifikansi $>0,05$. Nilai signifikansi yang dimaksud adalah nilai signifikansi antara indikator dengan total. Berdasarkan table output spss 17, diperoleh bahwa indikator valid yaitu, dengan rincian sebagai berikut :

Tabel 1. Hasil Uji Validitas dan Reabilitas

\begin{tabular}{llcl}
\hline & \multicolumn{1}{c}{ Variabel } & Cronbach's Alpha & Keterangan \\
\hline 1 & Tangible (x1) & 0.917 & Reability \\
2 & Realibility (X2) & 0.922 & Reability \\
3 & Responsivens (X3) & 0.941 & Reability \\
4 & Assurance (X4) & 0.943 & Reability \\
5 & Empahaty (X5) & 0.939 & Reability \\
6 & Kepuasan Konsumen (Y) & 0.949 & Reability \\
\hline
\end{tabular}


Hasil penelitian menunjukan bahwa tidak ada pengaruh tangible terhadap kepuasan konsumen pada toko Cahaya. Hal ini dibuktikan dengan hasil statistik uji t untuk variabel bukti fisik dengan nilai $t_{\text {hitung }}$ sebesar 2.063 dengan nilai signifikansi sebesar 0,000 lebih besar dari 0,05 $(0.000>0,05)$, dan koefisien regresi mempunyai nilai positif sebesar 1,167 . Hal ini menunjukkan bahwa variabel tangible secara parsial tidak ada pengaruh yang signifikan antara variabel tangible terhadap variabel kepuasan konsumen atau dengan kata lain Ho ditolak.

Hasil penelitian menunjukkan bahwa ada pengaruh signifikan terhadap kepuasan konsumen pada toko Cahaya. Hal ini dibuktikan dengan statistik uji $\mathrm{t}$ untuk variabel reliability dengan $\mathrm{t}_{\text {hitung }}$ sebesar 2.063 dengan nilai signifikansi sebesar 0,000 lebih kecil dari 0,05 $(0,000<0,05)$, dan koefisien regresi mempunyai nilai positif sebesar 1.180. Hal ini menunjukkan ada pengaruh yang signifikan antara variabel reability terhadap variabel kepuasan konsumenatau dengan kata lain, Ho ditolak.

Hasil penelitian menunjukkan bahwa variabel responsiveness atau daya tanggap memiliki pengaruh negative dan tidak berpengaruh signifikan terhadap kepuasan konsumen pada toko Cahaya. Hal ini dibuktikan dengan $t_{\text {hitung }}$ sebesar 2.063 dengan nilai signifikansi sebesar 0.031 lebih besar dari 0,05 (0,031>0,05), dan koefisien regresi mempunyai nilai sebesar .356. Hal ini menunjukkan bahwa variabel responsiveness secara parsial tidak ada pengaruh yang signifikan antara variabel responsiveness terhadap variabel kepuasan konsumen atau dengan kata lain, Ho ditolak.

Hasil penelitian menunjukkan bahwa variabel assurance atau jaminan memiliki pengaruh positif akan tetapi tidak berpengaruh signifikan terhadap kepuasan konsumen pada toko cahaya. Hal ini dibuktikan dengan $t_{\text {hitung }}$ sebesar 2.063 dengan nilai signifikansi sebesar 0,000 lebih besar dari 0,05 (0,000>0,05), dan koefisien regresi mempunyai nilai sebesar .732. Hal ini menunjukkan bahwa variabel assurance secara parsial tidak ada pengaruh yang signifikan antara bahwa variabel assurance terhadap variabel kepuasan konsumen dengan kata lain, Ho ditolak

Hasil penelitian menunjukkan bahwa variabel emphaty memiliki pengaruh positif akan tetapi tidak berpengaruh signifikan terhadap kepuasan konsumen pada toko cahaya. Hal ini dibuktikan dengan $t_{\text {hitung }}$ sebesar 2.063 dengan nilai signifikansi sebesar 0,000 lebih besar dari 0,05 $(0,000>0,05)$, dan koefisien regresi mempunyai nilai sebesar .600. Hal ini menunjukkan bahwa variabel emphaty secara parsial tidak ada pengaruh yang signifikan antara variabel emphaty terhadap variabel kepuasan konsumen dengan kata lain, Ho ditolak.

Hasil penelitian menunjukkan bahwa ada pengaruh tangible, reliability, responsiveness, assurance dan, emphaty terhadap kepuasan konsumen pada toko cahaya. Hal ini dibuktikan dengan hasil statistic $F_{\text {hitung }}$ sebesar 20,186 dengan signifikansi sebesar 0,000. Oleh karena nilai signifikansi lebih kecil dari $0,05(0,000<0,05)$, maka penelitian ini berhasil membuktikan hipotesis keenam yang menyatakan bahwa "terdapat pengaruh signifikan kualitas jasa pelayanan (tangible, reliability, responsiveness, assurance dan, emphaty) terhadap kepuasan konsumen".

Hasil uji determinan $\mathrm{R}^{2}$ pada penelitian ini diperoleh nilai determinan $\mathrm{R}^{2}$ sebesar 0,985 yang berarti bahwa besarnya pengaruh variabel tangible, reliability, responsiveness, assurance dan emphaty terhadap kepuasan konsumen adalah sebesar 98,5\% dan sisanya 1,5\% dijelaskan variabel lain yang tidak termasuk dalam penelitian ini.

\section{Kesimpulan}

\section{KESIMPULAN DAN SARAN}

Berdasarkan penelitian yang dilakukan pada took Cahaya di Kabupaten Murung Raya, maka dapat disimpulkan bahwa kualiats jasa pelayanan (variabel Tangible (Tb), variabel Reliability $(\mathrm{Rb})$, variabel Responsiveness (Rp), variabel Assurance (As), dan variabel Emphaty (Ep)) 
berpengaruh signifikan terhadap Kepuasan Konsumen pada Toko Cahaya. Dari rumusan masalah di atas, maka dapat ditarik beberapa kesimpulan:

\section{Saran}

Berdasarkan penelitian yang dilakukan pada took Cahaya di Kabupaten Murung Raya, maka dapat disarankan :

1. Toko Cahaya harus tetap memberikan pelayanan yang baik pada dimensi-dimensi lainnya.

2. Agar dapat memberikan tingkat kepuasan yang tinggi kepada konsumennya Pihak Toko Cahaya harus memperhatikan Emphaty, Asurance, Tangible, Responsivenes dan Reliability yang diberikan.

\section{DAFTAR PUSTAKA}

Algifari, 2000. Analisis Regresi Teori, Kasus dan Solusi. BPFE : Yogyakarta Arikunto, 2002. Prosedur Penelitian Suatu Pendekatan Praktek. Rineka Cipta : Jakarta

Atmawati, R \& M, Wahyudin. 2007. Analisis Pengaruh Kualitas Pelayanan. eprint-ums Solo Jawa Tengah

A.S. Moenir. 1998. Manajemn Pelayanan Umum di Indonesia. Jakarta : Bumi Aksara.

Brata. 2003. Dasar-dasar Pelayanan Prima. Gramedia : Jakarta

Dhion Gama Putra, Ratih Nur Pratiwi, Trisnawati. 2012. Pengaruh Kualitas Pelayanan Terhadap Kepuasan Masyarakat (Studi pada Dinas Kependudukan dan Pencatatan Sipil Kota Blitar). Jurnal Administrasi Publik UB Malang

Endar Sugiarto, 1999. Psikolosi Pelayanan Dalam Industri Jasa Penerbit Gramedia : Jakarta

Gespersz. 1997. Manajemen Kualitas. Gramedia : Jakarta

Kotler, 2007. Manajemen Pemasaran, Jilid 2, Edisi 12. Penerjemah ; PT Indeks

Kuswadi. 2004. Cara Mengukur Kepuasan Karyawan. Elex Media Komputindo: Jakarta

K.V.D.H.S.Kalutharawithana, N.S.Jayawardena, 2017. Dampak Kualitas Layanan terhadap kepuasan Pelanggan di Rumah Sakit Sektor Swasta- Studi Kasus di Rumah Sakit Swasta $\mathrm{ABC}$ di Sri Lanka. International journal of scientific \& engineering research volume 8 issue 12 issn 2229-5518

Lovelock, 1992. Managing Services: Marketing, Operations, and Human Resources. Englewood Cliffs : Prentice Hall

Mohd. Afroz Pasha, Dr. M. Razashah M.B.A. 2018. Dampak Kualitas Layanan terhadap Kepuasan Pelanggan: Studi Empiris di Bank Sektor Publik dan Swasta Terpilih. e-journal Unsrat Jurnal Seni, Sains \& Perdagangan, E-ISSN 2229-4686 I ISSN 2231-4172.

Ni Putu Resi Deepseani. 2017. Pengaruh Kualitas Pelayanan Terhadap Kepuasan Pelanggan Bus Trans Batam Di Kota Batam. Teknik analisis data yang digunakan adalah Structural Equation Modeling Smart Partial Least Square (SEM-SmartPLS 3.0). Skripsi. Polibatam

Pisciesha Qudsi Auliya. 2016. Pengaruh Tingkat Kualitas Pelayanan Terhadap Tingkat Kepuasan Pelanggan Listrik Pintar Prabayar Di PT. PLN (Persero) Area Pelayanan Surabaya. Jurnal Kebijakan dan Manajemen Publik Unair Volume 4, Nomor 1, Januari-April 2016 ISSN 2303 - 341X

Salim \& Woodward. 1992. Analisis Pelayanan Publik. Pustaka Pelajar. Yogyakarta

Siregar, S.,2010. Statistika Deskriptif untuk Penelitian, PT. Raja Grafindo

Sirhan Fikri, Wahyu Wiyani, Agung Suwandaru. 2016. Pengaruh Kualitas Pelayanan Terhadap Kepuasan Dan Loyalitas Mahasiswa. Jurnal Bisnis dan Manajemen Vol. 3 No.1, Januari 2016

Sugiyono, 2008. Metode Penelitian Kunatitatif Kualitatif dan R\&D. Alfabeta : Bandung

Supranto, 2000. Statistik Teori dan Aplikasi Jilid 1, Edisi Keenem. Erlangga, Jakarta 
Tjiptono Fandy, 2003. Prinsip-Prinsip Total Quality Service. Penerbit Andi, Yogyakarta Tjiptono Fandy, 2005. Prinsip-Prinsip Total Quality Service (Edisi Revisi). Penerbit Andi, Yogyakarta

Zeithaml, Valarie A, 1996. Services Marketing. Edisi1. Boston. MCGraw-Hill.

Zulian Yamit, 2004. Manajemen Kualitas Produk dan Jasa. Penerbit: Ekonisia, Yogyakarta 